\title{
ELEOCHARIS MUTATA (CYPERACEAE), NEW TO THE FLORA OF FLORIDA, U.S.A.
}

\section{Courtney L. Angelo}

\author{
Broward County Parks and Recreation Division \\ 950 NW 38th St. \\ Oakland Park, Florida 33309, U.S.A. \\ courtneyangelo@gmail.com
}

\section{David J. Rosen}

Lee College

Department of Biology

P.O. Box 818

Baytown, Texas 77522, U.S.A.

\author{
James J. Lange \\ Fairchild Tropical Botanic Garden \\ 10901 Old Cutler Rd., Coral Gables, Florida 33156, U.S.A. and \\ Broward County Parks and Recreation Division \\ 950 NW 38th St., Oakland Park, Florida 33309, U.S.A.
}

\section{ABSTRACT}

This is the first record of Eleocharis mutata in Florida, and the second record in the continental USA, suggesting a potential natural range expansion of this species from the Caribbean region. A key to species of Eleocharis subg. Limnochloa in Florida is included, along with a site description of the occurrence, visual aids for identification, and a brief discussion of nativity.

KEY Words: Eleocharis mutata, range expansion, nativity, Florida, new record

\section{RESUMEN}

Esta es la primera cita de Eleocharis mutata en Florida, y la segunda en los Estados Unidos continental USA, que sugiere una expansión potencial natural del rango de esta especie de la región caribeña. Se incluye una clave de especies de Eleocharis subg. Limnochloa en Florida, junto con una descripción del lugar de ocurrencia, ayudas para la identificación, y una breve discusión acerca de si es nativa.

\section{INTRODUCTION}

Recent field work in Broward County, southeast Florida, uncovered a population of Eleocharis mutata (L.) Roem. \& Schult. (Fig. 1). From a distance, the population resembled either E. interstincta (Vahl) Roem. \& Schult. or E. cellulosa Torr., two common Eleocharis R. Br. species in the flora of South Florida (Gann et al. 2019). However, after closer field examination, triquetrous culms were distinguishable on all individuals (rather than the terete culms characteristic of E. interstincta and E. cellulosa, Fig. 2). Using the Guide to the Vascular Plants of Florida (Wunderlin \& Hansen 2011) the material keyed to E. acutangula (Roxb.) Schult., the only triquetrous-culmed Eleocharis known from Florida. However, after referring to Rosen et al. (2007), the specimens did not match E. acutangula in details of the achenes. Specimens were sent to the second author for examination. He confirmed that the specimen was Eleocharis mutata, not previously known from the state of Florida (Wunderlin \& Hansen 2011; Gann et al. 2019; Wunderlin et al. 2019). Our collection represents the second report of E. mutata to the flora of the continental USA, the first being from Brazoria and Goliad Counties in southeastern Texas (Rosen \& Jones 2004).

Voucher specimen: U.S.A. FLORIDA. Broward Co.: West Lake Park, one clonal patch $\sim 25 \mathrm{~m}^{2}$ in mud flat adjacent to mangroves, 26.029996 -80.120237, 24 Jul 2019, J. Lange 153 with C. Angelo (FTG, TEX, USF; Fig. 3).

Eleocharis mutata belongs to subg. Limnochloa (P. Beauv. ex T. Lestib.) Torr., a group of over 35 species distributed throughout tropical and subtropical regions worldwide, most being robust emergent plants forming extensive stands in wetlands. Species in the subgenus are readily distinguished from other spikerushes by a combination of cartilaginous floral scales with prominent longitudinal veins, culms that are usually as wide as the cylindrical spikelets, and biconvex (or rarely trigonous) achenes with usually large polygonal epidermal cells arranged in longitudinal rows (González-Elizondo \& Peterson 1997). The addition of E. mutata brings the total number of species of subg. Limnochloa in Florida to eight. Mature fruiting specimens can be readily identified using this key: 


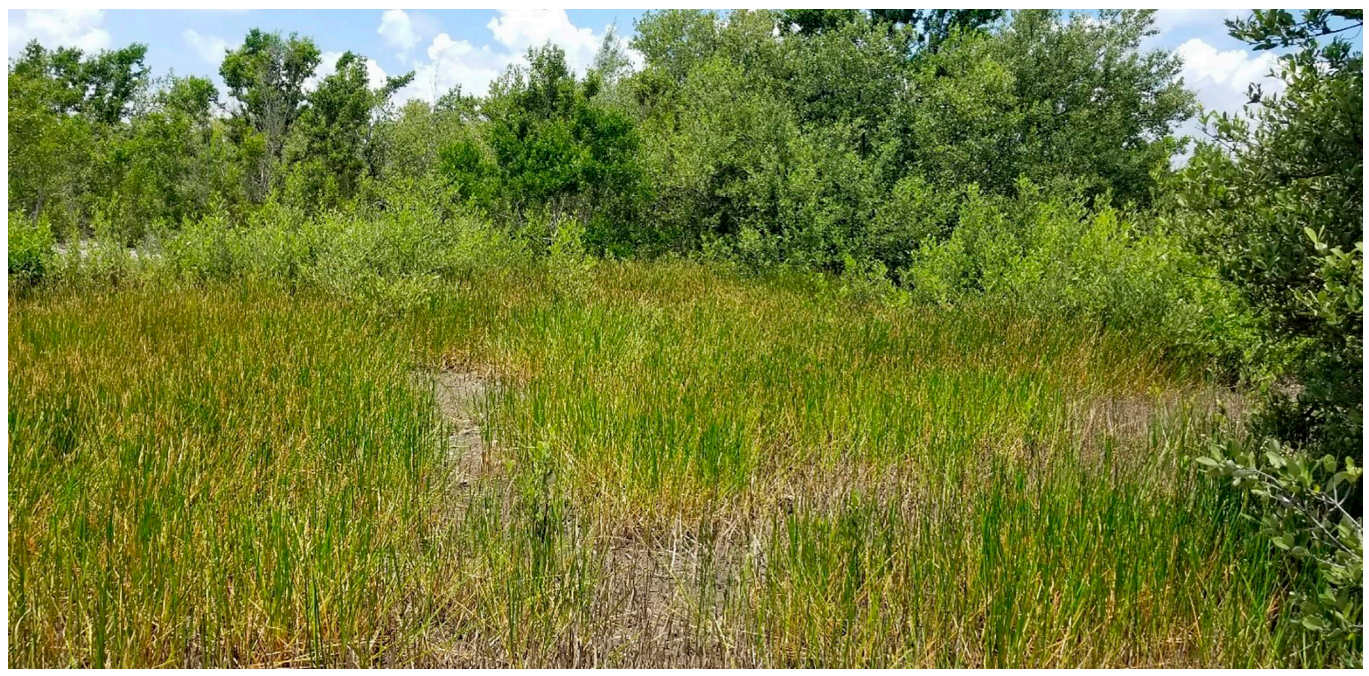

Fig. 1. Dense colony of E. mutata in July 2019 at West Lake Natural Area, Broward County, Florida.

\section{KEY TO SPECIES OF ELFOCHARIS SUBG, LIMNOCHLOA IN FLORIDA}

1. Culms hollow, complete transverse septate.

2. Perianth bristles longer than the achene, coarsely retrorsely spinulose; achenes conspicuously sculptured at 10-15X; culm septa extending up the culm to immediately below spikelet

Eleocharis interstincta

2. Perianth bristles much shorter than the achene, thin and soft, without teeth; achenes not conspicuously sculptured at 10-15x, appearing nearly smooth; culm septa extending up the culm to well short of spikelet

1. Culms internally spongy, incomplete transverse septate.

3. Culms sharply-quadrangular

3. Culms triquetrous to terete.

4. Spikelets $3 \mathrm{~mm}$ or less wide; achene $0.5-1.4 \mathrm{~mm}$ wide; plants sometimes forming submerged aquatic forms with flaccid culms bearing whorled branches.

5. Floral scales 3.5-4.5 mm long; achene 0.65-1.4 long x 0.5-0.8 mm wide; tubercles dark brown, pyramidal, somewhat merging with the achene apex Eleocharis elongata

5. Floral scales 5-7.8 mm long; achene 1.9-2.6 long x 1-1.4 mm wide; tubercles stramineous to medium brown, separated from the achene apex by a short neck Eleocharis robbinsii

4. Spikelets 3.5-8 $\mathrm{mm}$ wide; achene 1.4-1.8 $\mathrm{mm}$ wide; plants not observed to form submerged aquatic forms with flaccid culms, either emergent or terrestrial.

6. Culms terete or distally obscurely 3-angled, never triquetrous; perianth bristles usually smooth

6. Culms triquetrous; perianth bristles retrorsely spinulose.

7. Floral scales ovate to broadly ovate, finely cellular-lineate veined (raised veins not clearly discernible at 20x); achene apex slightly constricted at the summit into a hard annular thickening; perianth bristles straighttortuous, irregularly retrorsely spinulose (Fig. 4 a-b)

Eleocharis mutata

7. Floral scales ovate-oblong, coarsely veined (raised veins clearly discernible at 20x); achene apex markedly constricted to a short neck; perianth bristles straight, coarsely retrorsely spinulose (Fig. 4 c-d)

Eleocharis acutangula

\section{DISCUSSION}

Site description.-Eleocharis mutata was discovered in an isolated artificial landmass within mangrove forests along the Intracoastal waterway in Broward County, where public access is restricted. The substrate in the area is local fill that was brought to the site when the area was slated for residential development prior to the county acquiring the land. The area where E. mutata has colonized is lower in elevation than the surrounding substrate and forms a depression with deep, mucky soil. From aerial imagery, the depression appears to have been created during a mitigation project in 1999 and oscillates in color seasonally from green to brown between 1999-2018 (Google Earth Pro 2020) suggesting that E. mutata could have been at the site for almost 20 years without detection. Eleocharis mutata forms a large, $25 \mathrm{~m}^{2}$ colony in this depression where it coexists with 


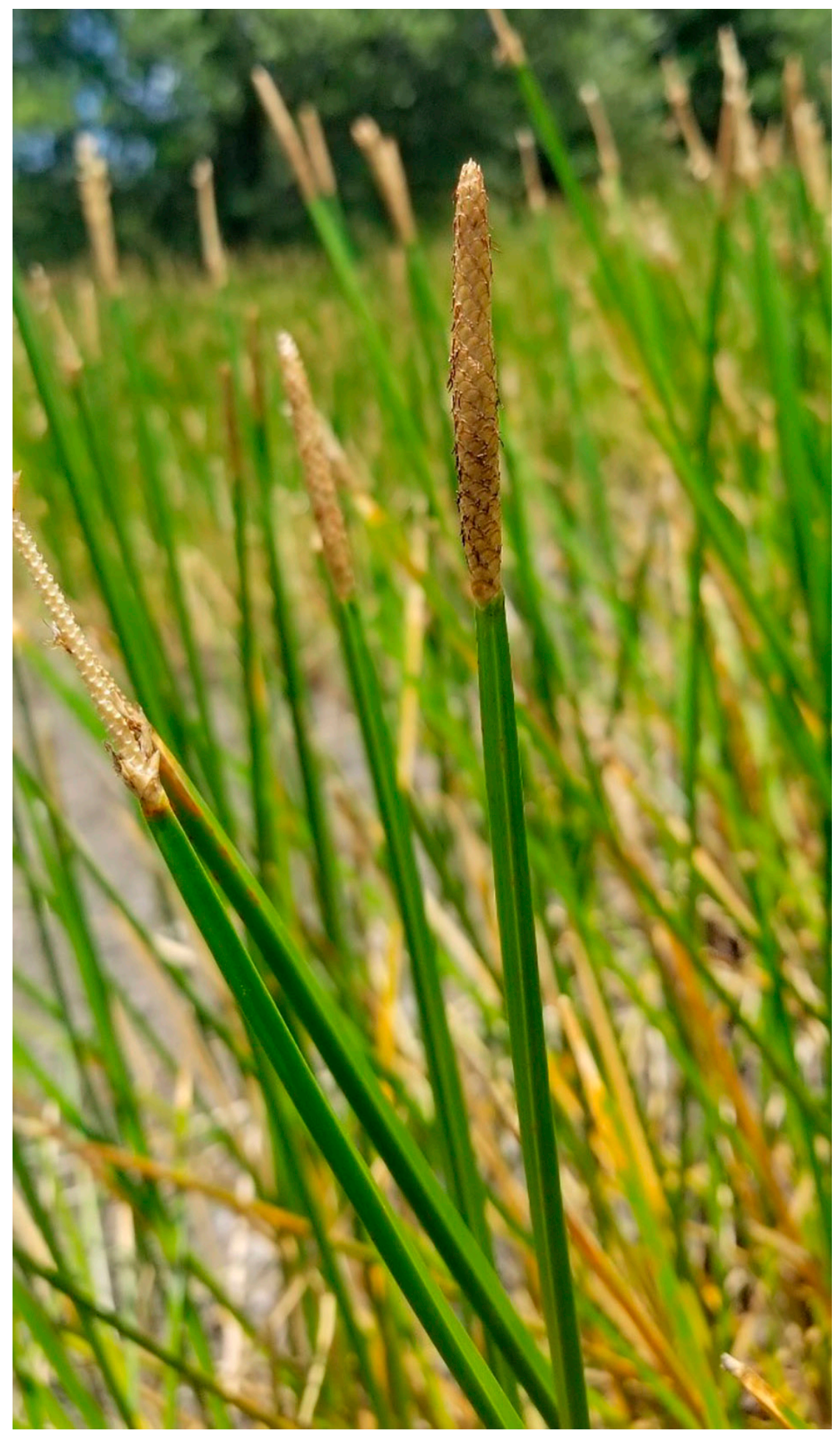




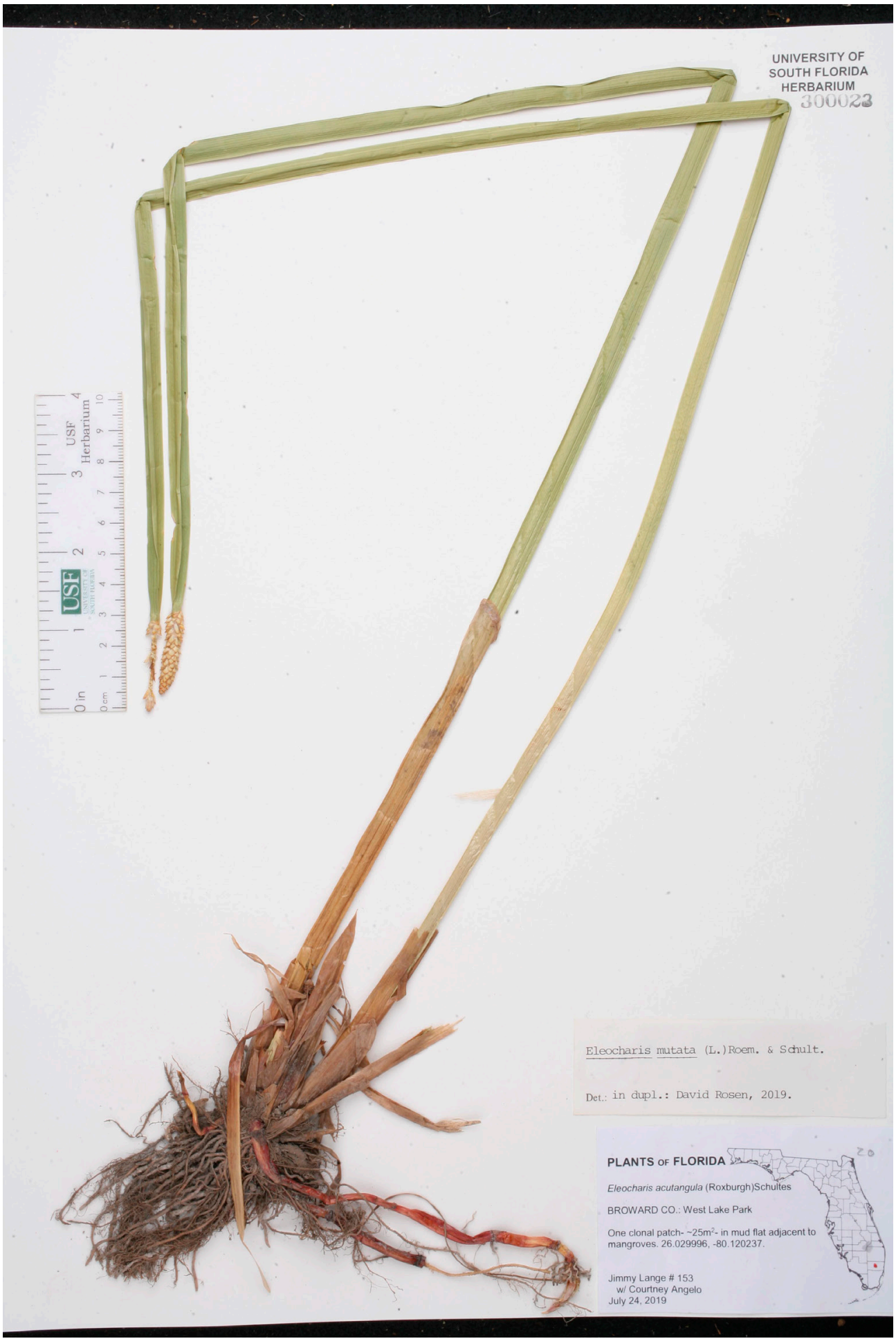

FIG. 3. Voucher specimen of E. mutata from Broward County, Florida (Lange 153 with C. Angelo, FTG, TEX, USF). 


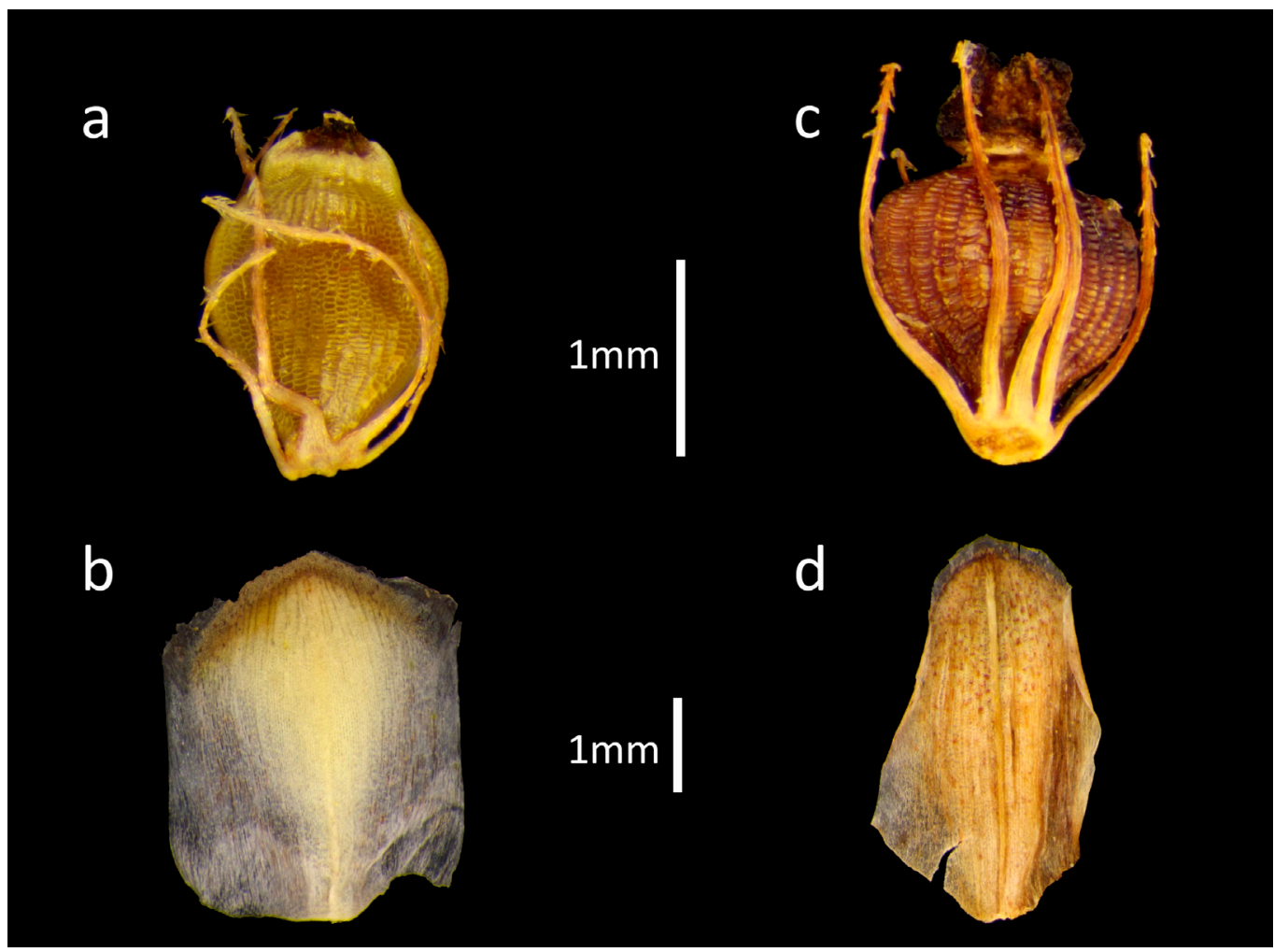

Fig. 4. Micrographs of Eleocharis mutata (a) achene and (b) floral scale; Micrographs of Eleocharis acutangula (c) achene and (d) floral scale (a-b Lange 153, FTG; c-d Woodmansee 1624, FTG).

Avicennia germinans (L.) L. (black mangrove), along with small patches of Laguncularia racemosa (L.) C.F. Gaertn. (white mangrove) around its perimeter (Fig. 1). The area is subject to periodic extreme high tide events, i.e. King Tides, that occur in the spring and fall in South Florida, inundating the depression and surrounding upland with saltwater. Similar vegetation and habitat conditions have been reported for this species in Mexico (Rio Tonala, Veracruz, pers. comm., David Rosen). Additionally, the species has been found in freshwater marshes, mud flats and wet depressions, salt ponds, and near the coast along the border of mangrove forests in its native distributional range (Tropicos.org 2020). Other plant species in the general area of our E. mutata population include Conocarpus erectus L. (buttonwood), Lantana involucrata L. (buttonsage), Coccoloba uvifera (L.) L. (seagrape), Pteris bahamensis (J. Agardh) Fée (bahama ladder brake), and Borrichiafrutescens (L.) DC. (bushy seaside oxeye).

Eleocharis mutata has been reported as native to Mexico (excluding Baja California), the Caribbean Islands, north and central South America, and countries along the West Coast of Africa (Rosen et al. 2008). Similar to the occurrence in Texas, the nativity of E. mutata in Florida is also unclear, though it has been tentatively listed by the Atlas of Florida Plants as a non-native species (Wunderlin et al. 2019). The closest documented native population to ours is from Eleuthera, Bahamas (Rosen, unpublished data), roughly $660 \mathrm{~km}$ to the southeast with $\leq 1.5$ degrees change in latitude (Correll \& Correll 49001; MO, NY).

There is no way to determine if this species dispersed to South Florida via anthropogenic channels or if it is an example of a natural range expansion from the Bahamas or other parts of the Caribbean region via mechanisms such as migratory birds, currents, or tropical storms. Both situations seem equally plausible. 
Birds have been shown to be common vectors of long-distance dispersal of plant propagules in the Cyperaceae (Bryson \& Carter 2008; Villaverde et al. 2015), including being effective dispersers of species in the genus Eleocharis (Bryson \& Carter 2008). Furthermore, in Florida alone there have been over 53 storms ranging from depressions to hurricanes over the last 30 years that have intersected the state from the Gulf of Mexico, Caribbean Sea, or Atlantic Ocean, offering many opportunities for long-distance dispersal events (NOAA Historical Hurricane Tracks 2020). Over that 30-year time period at least ten other sedges have been discovered in Florida (Jacono 2001; Carter et al. 2016; Brunton et al. 2018; pers. comm., Alan Franck 2019), most of which have broad geographic ranges that include the Caribbean, and are not known to be distributed in horticultural trades. Species capable of colonizing island chains clearly must possess dispersal traits and habitat requirements that allow them to disperse long distances and successfully colonize new areas. Over time, and particularly in the face of global climate change, such dispersal is inevitable, and we must be willing to accept new members of our native flora in cases where human intervention seems unlikely.

\section{ACKNOWLEDGMENTS}

We thank Broward County's Natural Areas Trust Fund and the Rare Plant Program it supports for funding plant inventories that led to this and other discoveries. We would like to thank Jack Hahn and the Imaging Laboratory of the Hsiao Laboratories complex at Fairchild Tropical Botanic Garden for the micrographs of E. mutata and E. acutangula, along with Erik Eckles for arranging the images into a comparative panel for this manuscript. We would additionally like to acknowledge the three herbaria that house vouchers of Eleocharis mutata from our field site in Florida: Fairchild Tropical Botanic Garden, University of South Florida, and the University of Texas. Lastly, we thank Richard Carter and Alan Franck for comments and reviews on an earlier draft which much improved our manuscript.

\section{REFERENCES}

Brunton, D.F., J.R. Campbell, \& A.A. Reznicek. 2018. Eleocharis elegans (Cyperaceae) new to Florida and a possible native addition to the Flora of the United States. J. Bot. Res. Inst. Texas 12(1):249-255.

Bryson, C.T. \& R. CARTER. 2008. Sedges: Uses, diversity, and systematics of the Cyperaceae In: R.F.C. Naczi \& B.A. Ford, eds. The significance of Cyperaceae as weeds, Missouri Botanical Garden Press, St. Louis, Missouri, U.S.A. Pp. 15-101.

Carter, R., R.L. Mears, R.H. Goddard, \& C.T. Bryson. 2016. Cyperus richardii (Cyperaceae) new to Florida, USA, and the western hemisphere. J. Bot. Res. Inst. Texas 10(1):191-200.

Gann, G.D., C.G. Stocking, \& Colloborators. 2001-2019. Floristic inventory of South Florida database online. Available at regionalconservation.org/ircs/database/database.asp. Accessed November 2019.

Google EARth Pro. 2020. Available at google.com/earth/versions/\#download-pro. Accessed November 2019.

González-Elizondo, M.S. \& P.M. Peterson. 1997. A classification of and key to the supraspecific taxa in Eleocharis (Cyperaceae). Taxon 46:433-449.

JACONo, C.C. 2001. Scleria lacustris (Cyperaceae), an aquatic and wetland sedge introduced to Florida. Sida 19(4):1163-1170.

Noaa Historical Hurricane Tracks. 2020. Available at coast.noaa.gov/hurricanes/. Accessed November 2019.

Rosen, D.J. \& S.D. Jones. 2004. Eleocharis mutata (Cyperaceae) new to the flora of North America north of México. Sida 21(2):1153-1160.

Rosen, D.J., S.L. HATCH, \& R. CARTER. 2007. Infraspecific taxonomy and nomenclature of Eleocharis acutangula (Cyperaceae). J. Bot. Res. Inst. Texas 1(2):875-888.

ROSEn, D.J., S. L. HATCH, \& R. CARTER. 2008. Taxonomy and nomenclature of three closely related species of Eleocharis subg. Limnochloa (Cyperaceae). Blumea 53:235-246.

Tropicos.Org. 2020. Available at tropicos.org. Accessed November 2019.

Villaverde, T., M. Escudero, M. Luceno, \& S. Martín-Bravo. 2015. Long-distance dispersal during the middle-late Pleistocene explains the bipolar disjunction of Carex maritima (Cyperaceae). J. Biogeogr. 42:1820-1831.

WUNDERLIN, R.P. \& B.F. HANSEN. 2011. Guide to the flora of Florida. University of Florida Press, Gainesville, FL, U.S.A.

Wunderlin, R.P., B.F. Hansen, A.R. Franck, \& F.B. Essig. 2019. Atlas of Florida Plants. Available at florida.plantatlas.usf.edu. Institute for Systematic Botany, University of South Florida, Tampa, Florida, U.S.A. 